\title{
CYATHEA LAMOUREUXII (CYATHEACEAE): A REMARKABLE NEW SPECIES FROM THE PAPUAN PENINSULA OF NEW GUINEA
}

\author{
W. TAKEUCHI \\ Arnold Arboretum and the Herbaria of Harvard University, \\ c/o PNG National Forest Authority, \\ P.O. Box 314, Lae, Morobe Province 411, Papua New Guinea
}

\section{SUMMARY}

Cyathea lamoureuxii is described from recent exploratory surveys in Papua New Guinea. The new fern is unique among eastern Malesian congeners for its undivided pinnae, and is also the only member of its subgenus with manifestly pinnate leaves. The manner in which the novelty combines diagnostic features across infrageneric lines underscores the difficulties in drawing absolute separations at the subgenus and sectional levels.

Key words: Cyathea, Schizocaena, Sphaeropteris, ultrabasics.

\section{INTRODUCTION}

Cyathea tree ferns are among the most prominent and photogenic elements in the Papuasian flora. The genus is common at all elevations and provides the defining component for at least one landscape formation (i.e., the subalpine tree fern savannah; Fig. 1).

In the generic circumscription adopted by Holttum (1963), 78 species are recognized for the New Guinea mainland. Tryon's (1970) newer classification increases the difficulties present in Cyathea taxonomy, and has not been followed in this paper.

Pteridology has rarely been a focus of botanical exploration in New Guinea. Except for the activities of a few specialists (e.g., J. Croft, J.S. Croxall, A.C. Jermy, T. Nakaike,

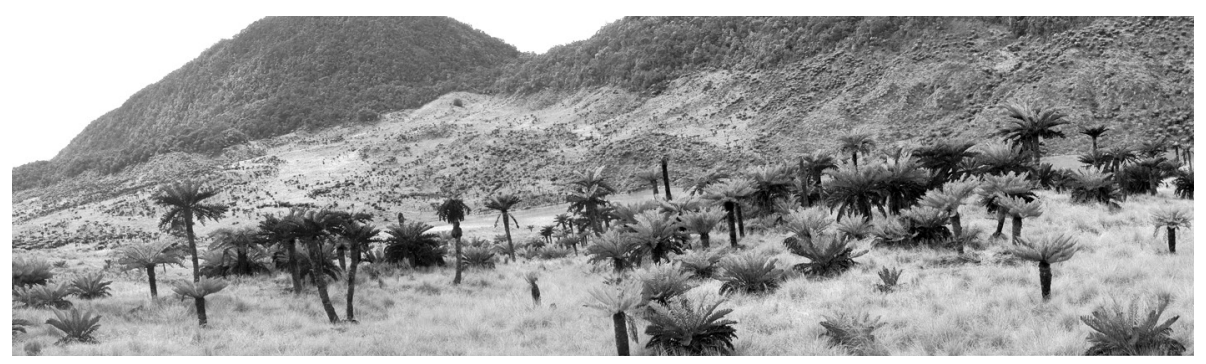

Fig. 1. Cyathea tree fern savannah from the Kaijende Highlands of Enga Province, Papua New Guinea. Cyathea dicksonioides and C. atrox var. inermis are codominants in the subalpine community. Photo by W. Takeuchi. 
and B.S. Parris) collecting has been primarily inconsequential and opportunistic. Although floristic documentation has improved in most respects, the historical malaise for ferns has become especially acute in recent years. With Cyathea in particular, the current inactivity can be partly attributed to the large size of most species and the corresponding difficulty in making effective collections. The impediments and disincentives are comparable to the situation for palms, another group where non-specialist field workers are understandably reluctant to expend special effort.

Despite their common perception as 'tree ferns', Cyathea is not always composed of large plants. A fair number of Malesian species are short statured (1-2 m tall), in marked contrast to the arborescent representatives for which the genus is characteristically associated. Not surprisingly, the smaller taxa (e.g., C. microphylloides, C.perpelvigera) are usually better represented in herbaria. The following account presents a new and distinctive member of this latter assemblage and briefly discusses the implications of its unexpected discovery.

\section{DESCRIPTION}

\section{Cyathea lamoureuxii W. Takeuchi, spec.nov. - Fig. 2, 3; Map 1}

Inter species subgeneris Cyatheae singularis ob folia valde pinnata. - Typus: Takeuchi, Ama, Siga \& Kavua 16190 (holo LAE; iso A, L), Papua New Guinea, Morobe Province, Siboma Bay, alt. 50 m, 25 April 2002.

Terrestrial fern. Caudex erect, c. $7 \mathrm{~cm}$ tall, cylindrical, unbranched, cicatricatous on the lower part, furnished with persisting stipe bases near the top, leaves tufted the summit. Stipes $12-17(-24) \mathrm{cm}$ by $3-5 \mathrm{~mm}$, conspicuously channelled on the dorsal side, rounded beneath, pallid; vasculature of numerous strands in 3 elongate arcs, upwardly coalescing into \pm continuous bands; pneumathodes interrupted, arranged in

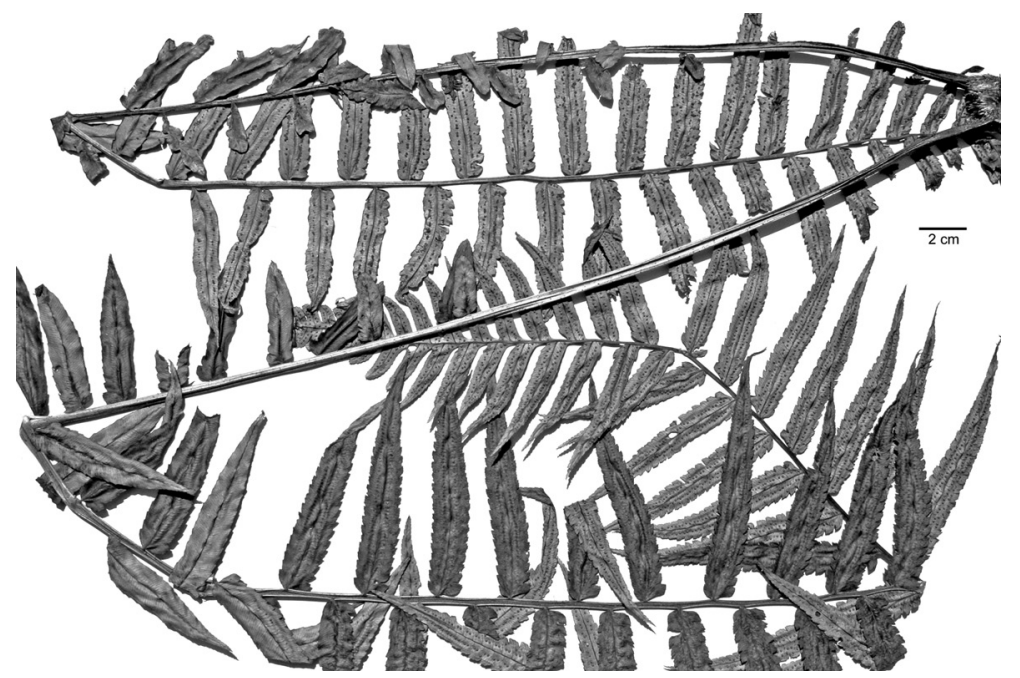

Fig. 2. Cyathea lamoureuxii W. Takeuchi. Unmounted duplicate (caudex removed) showing two whole fronds (Takeuchi et al. 16190). 
2 longitudinal lines per side, pallescent, obscure; scale indument: scales linear, 7-10.5 by $0.4-1.2(-2.2) \mathrm{mm}$, firm, appressed or not, bicolorous, median sections dark brown, margins hyaline, flabelloid, paleae congested on lower parts of the stipe, distally lax, falling early, bases persisting as a muricate-conoidal residue; hair indument: hairs setiform, subulate, septate, antrorsely arcuate, mostly confined to the dorsal channel, shining, dark brown. Rachis 77-90 cm long, indument as the stipe but hairs denser in channels; scales elongate, crispate, transitional in form to setiferous scales. Lamina pinnate, 26-32 pinnae per side, decrescent, widest at the middle; apical part pinnatisect, narrowly deltate, $9.5-16$ by $6-8.5 \mathrm{~cm}$, lobes obtuse. Basal pinna $12-24$ by 6-9 mm, sessile, truncate, with or without an auriculiform acroscopic lobule, margins parallel, subentire, apex obtuse or acute. Largest pinna 110 by $15 \mathrm{~mm}$; base sessile or obscurely $(<0.5 \mathrm{~mm})$ stipitate, truncate or oblique, wider on the acroscopic side; margins notched 1/4 the distance to costae or less, crenations asymmetric, extrorse, falcately acute, shallowly toothed; passing gradually to a prolonged and serrulate apex; upper surfaces proximally provided with setiform hairs on costae, glabrescent; undersurfaces glabrous or with scattered linear-dendritic scales. Venation catadromous, simple or pinnatiform, free, reaching the margin or nearly so, vein groups (2-)4-10(-13)nerval, uni- or binerval at pinnae apices, never confluent with adjacent groups, basal basiscopic veins emerging directly from costae, (0.2-)1-2 mm away from costules, each crenation served by one vein group; costae prominent on both surfaces, higher order nervation bifacially prominulous. Sori superficial on simple veins or in axils of bifurcating veins, seated on capitate or ellipsoid receptacles, globose, forming 1 (or 2) rows on either side of the midrib, (1-)2-4(-5) per vein group; filiform-paraphysate, the filaments compressed, catenate, eglandular, dark brown, numerous. Indusia chaffy, hyaline, fragile, at first a complete envelope closely appressed to sporangia, later open at the summit, finally rupturing irregularly nearly to the base, persisting as a scarious residue after spore discharge.

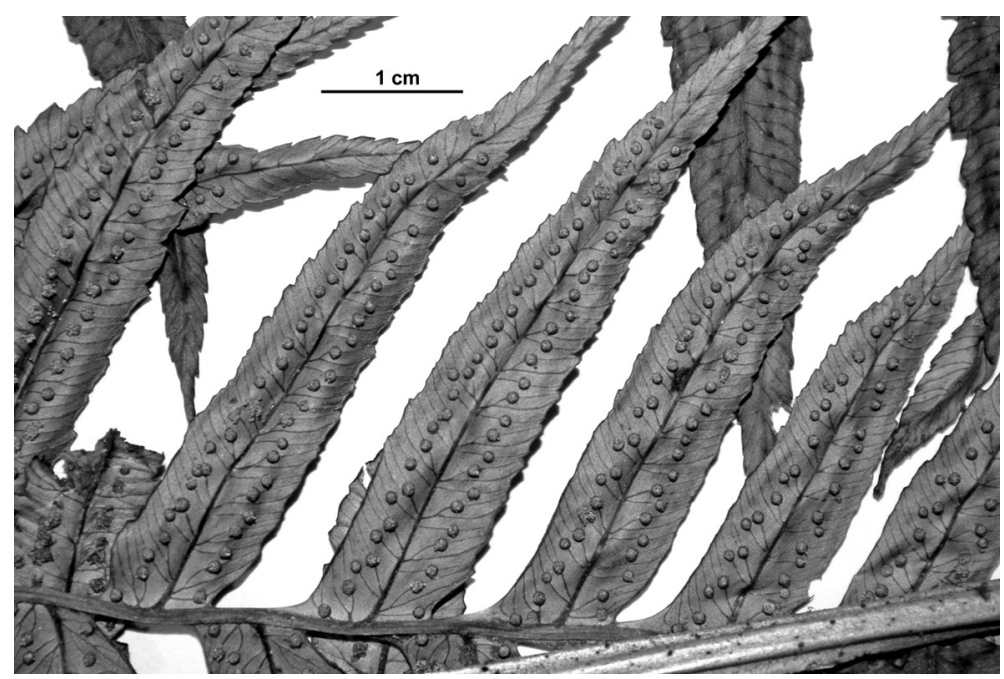

Fig. 3. Cyathea lamoureuxii W. Takeuchi. Pinnae detail from a subapical leaf section (Takeuchi et al. 16190). 


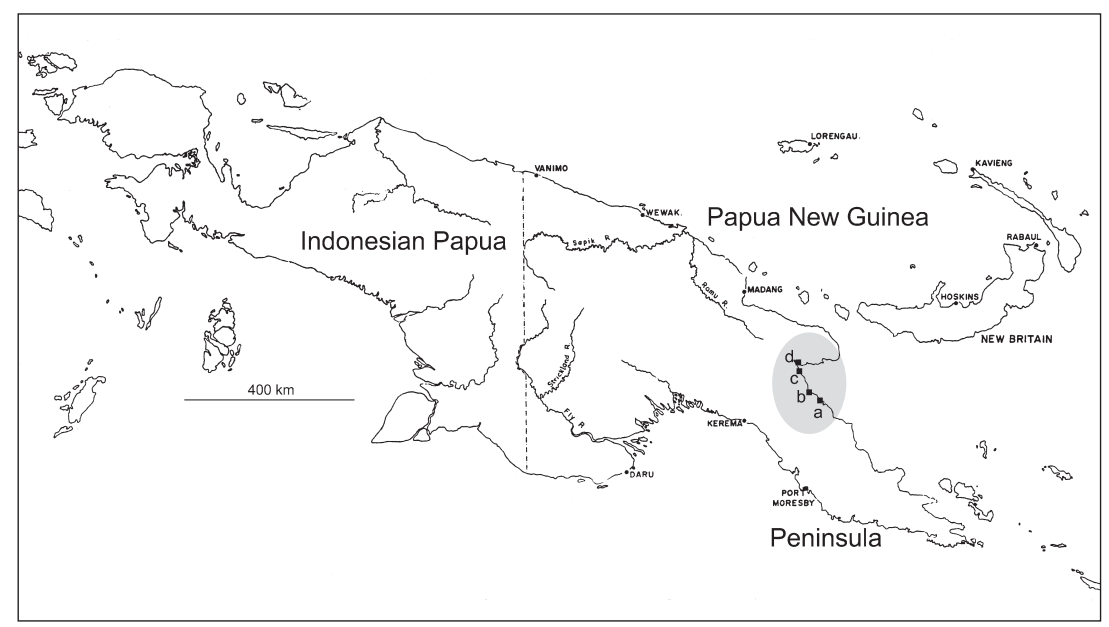

Map 1. Island of New Guinea. Localities mentioned in the text. a. Siboma; b. Kui-Lababia boundary; c. Salamaua; d. Lae-Markham subdistrict.

Field notes - Fronds obliquely ascending or cernuous; stipes greenish brown; lamina subcoriaceous, dark dull green above, pale green beneath.

Distribution - Known only from the type locality.

Habitat \& Ecology - Understory umbrophile in coastal forest selectively logged during the 1970s. Occurring in remnant stands uncut by the earlier operations.

Etymology - The epithet commemorates the life and contributions of Prof. Charles Lamoureux (1933-2000), the late pteridologist and educator from the University of Hawaii.

Notes - 1. In overall aspect, leaf structure, indument, and venation, the new species is similar to congeners from the moluccana group of section Schizocaena, subgenus Sphaeropteris. The once-pinnate leaves and the position of basal basiscopic nerves (emerging directly from costae) should ordinarily indicate affinity to C.moluccana and its allies (spp. 152-155 in Holttum, 1963). However with stipe scales that are obviously flabelloid, C. lamoureuxii is clearly to be placed in section Cyathea, within which it is immediately distinguished by its Schizocaena-like features. In several key respects, the novelty is a composite of character states from otherwise separate sectional facies (Table 1). The absence of sharp infrageneric divisions in Cyathea argues against the reassignments proposed by Tryon (1970) for Malesian taxa. Holttum (1981) summarizes some of the difficulties.

2. Within Papuasia, C. lamoureuxii is the only member of the genus with clearly undivided pinnae. In $C$. klossii and $C$. ascendens the pinnae are technically simple, but the lamina is so deeply bipinnatisect (divided 1-2 mm from costae) as to appear decompound. Among the dimorphic species in section Gymnosphaera, the sterile leaves of $C$. biformis are also once-pinnate, but the species is bipinnate when fertile, and has so many other contrasting characters (e.g., a climbing habit, exindusiate sori, vein groups without separately inserted costal nerves) that it could never be mistaken for $C$. lamoureuxii. 
Because of its singular qualities, the novelty can easily be accommodated in Holttum (1963: 77) by adding a new fork to the first couplet for section Cyathea:

1a. Lamina pinnate, pinna entire or crenato-serrate . . . . . . Cyathea lamoureuxii

b. Lamina bipinnatisect or divided to higher orders ..... to the existing couplet 1

3. The new fern is one of the smallest Cyathea in eastern Malesia. Measured from caudex base to the leaf apex, the total length is only $120 \mathrm{~cm}$.

4. The discovery of $C$. lamoureuxii occurred in conjunction with explorations focused on the Papuan ultrabasic flora (Takeuchi, 2003). Although not part of the ultrabasic series, the Siboma vegetation has numerous floristic elements in common with the serpentine formations across the Kui-Lababia contact (see geology in Dow \& Davies, 1964). Some investigators (e.g., Heads, 2003; Polhemus, 1996; Van Welzen, 1997) discount the influence of ultrabasic substrates on floristic patterns, regarding any correlations as coincidental to more fundamental and underlying causes connected to tectonics. Irrespective of the real underpinnings for endemic distributions in the Papuan belt, there is no question that the Peninsula comprises a discrete geofloristic unit. This is evident even from casual examination of species distributions within genera such as Aglaia (Pannell, 1992), Myristica (De Wilde, 1995), and Parsonsia (Middleton, 1997). All the range-limited endemics censused by recent survey at Siboma-Kamiali fail to

Table 1. Comparison of the pinnately-leaved species of Malesian Cyathea, with respect to characters regarded by Holttum (1963) as being more or less diagnostic for infrageneric separations. Cyathea biformis (section Gymnosphaera) is omitted from the tabulation on account of its bipinnate fertile leaves. The stipe-scale terminology (viz., flabelloid, setiferous) is used in the sense established by Holttum. For purposes of convenience, 'complete' refers to indusia which initially envelop the sorus as a discrete membrane, later tearing into scale-like fragments upon spore release. Where the applicable character state cannot be determined with certainty from the literature, this is explicitly indicated by '?'. Types have not been examined.

\begin{tabular}{|c|c|c|c|c|c|c|}
\hline Species & Section & $\begin{array}{l}\text { Stipe } \\
\text { scales }\end{array}$ & $\begin{array}{l}\text { Pinna } \\
\text { margin }\end{array}$ & $\begin{array}{l}\text { Vein } \\
\text { groups }\end{array}$ & Indusia & $\begin{array}{l}\text { Indument on } \\
\text { abaxial costae }\end{array}$ \\
\hline C.ascendens & Cyathea & flabelloid & pinnatisect & $\begin{array}{l}\text { costal vein } \\
\text { absent }\end{array}$ & exindusiate & $\begin{array}{l}\text { crisped hairs and } \\
\text { setiferous scales }\end{array}$ \\
\hline C. klossii & Cyathea & flabelloid & pinnatisect & $\begin{array}{l}\text { costal vein } \\
\text { absent }\end{array}$ & complete & bullate scales \\
\hline C. lamoureuxii & Cyathea & flabelloid & crenato-serrate & $\begin{array}{l}\text { costal vein } \\
\text { present }\end{array}$ & complete & glabrous \\
\hline C. angustipinna & Schizocaena & setiferous & entire to crenate & $\begin{array}{l}\text { costal vein } \\
\text { present }\end{array}$ & complete & glabrous \\
\hline C. arthropoda & Schizocaena & setiferous & \pm entire & $\begin{array}{l}\text { costal vein } \\
\text { present }\end{array}$ & $\begin{array}{l}\text { basal ring, } \\
\text { or absent }\end{array}$ & ?glabrous \\
\hline C. capitata & Schizocaena & setiferous & entire & $\begin{array}{l}\text { costal vein } \\
\text { present }\end{array}$ & complete & $?$ \\
\hline C.deminuens & Schizocaena & setiferous & pinnatifid & $\begin{array}{l}\text { costal vein } \\
\text { present }\end{array}$ & exindusiate & $\begin{array}{l}\text { hairy, scales } \\
\text { absent }\end{array}$ \\
\hline C.moluccana & Schizocaena & setiferous & \pm entire & $\begin{array}{l}\text { costal vein } \\
\text { present }\end{array}$ & complete & usually glabrous \\
\hline
\end{tabular}


cross the tectonic boundary at Salamaua. On the basis of known floristic patterns in south Morobe, $C$. lamoureuxii is probably a peninsular endemic. Future collections of this unusual fern should occur to the east, further into the Papuan zone, and are very unlikely to be made west of the Lae-Markham subdistrict.

\section{ACKNOWLEDGEMENTS}

My activities in Papuasian botany are supported by the National Science Foundation (grant DEB 0315930), the Arnold Arboretum, and the Herbaria of Harvard University.

\section{REFERENCES}

De Wilde, W.J.J.O. 1995. Census of Myristica (Myristicaceae) in New Guinea anno 1994. Blumea 40: 237-344.

Dow, D.B. \& H.L. Davies. 1964. The geology of the Bowutu Mountains, New Guinea. Australia Bur. Mineral Resources, Geology \& Geophysics Rept. 75: 1-31.

Heads, M.J. 2003. Ericaceae in Malesia: vicariance biogeography, terrane tectonics and ecology. Proceedings of the 5th International Flora Malesiana Symposium 2001. Telopea 10: 311-449.

Holttum, R.E. 1963. Cyatheaceae. Flora Malesiana, Ser. II, 1: 65-176.

Holttum, R.E. 1981. Addenda, corrigenda et emendanda. Flora Malesiana, Ser. II, 1: 561-564.

Middleton, D.J. 1997. A revision of Parsonsia R.Br. (Apocynaceae) in Malesia. Blumea 42: 191248.

Pannell, C.M. 1992. A taxonomic monograph of the genus Aglaia Lour. (Meliaceae). Kew Bull., Addit. Ser. 16. Royal Botanic Gardens, Kew.

Polhemus, D.A. 1996. Island arcs, and their influence on Indo-Pacific biogeography. In: A. Keast \& S.E. Miller (eds.), The origin and evolution of Pacific island biotas, New Guinea to eastern Polynesia: patterns and processes: 51-66. SPB Academic Publishing, Amsterdam.

Takeuchi, W. 2003. Botanical summary of a lowland ultrabasic flora in Papua New Guinea. Sida 20, 4: 1491-1559.

Tryon, R. 1970. The classification of the Cyatheaceae. Contr. Gray Herb. 200: 1-53.

Van Welzen,P.C. 1997. Increased speciation in New Guinea: tectonic causes? In: J. Dransfield, M.J.E. Coode \& D.A. Simpson (eds.), Plant diversity in Malesia III. Proceedings of the Third International Flora Malesiana Symposium 1995: 363-387. Royal Botanic Gardens, Kew. 